\title{
Correlações entre variação de tom e discurso em textos lidos 8
}

\author{
Vitor Pereira
}

\section{Objetivos.}

O objetivo deste trabalho é verificar a correlação entre a variação de tom e discurso em português brasileiro (PB) em textos lidos em voz alta. Procuramos uma possível lógica de variação tonal para a expressão de informação triste/desagradável ou feliz/agradável, com tom mais grave para a primeira e tom mais agudo para a segunda, conforme verificado por Luciano (2000) em amostras de discurso jornalístico e por Wennerstrom (2001) em fala espontânea e em textos lidos.

\section{Metodologia.}

Neste trabalho propomos uma análise baseada na proposta de Ferreira Netto (2006; 2008). A prosódia é tomada como série temporal, com as componentes: sustentação, finalização, foco/ênfase e acento lexical. Não será analisada a estrutura semântica, apenas a variação tonal e a frequência média, em hertz.

Para a coleta de dados desta amostra, extraí 30 amostras de áudio, dos sites brasileiros

8 SIMPÓSIO INTERNACIONAL DE INICIAÇÃO CIENTÍFICA/USP - SIICUSP, 17. São Paulo, 2009. 
- g1.globo.com;maisband.band.com.br;

- www.redetv.com.br;www.youtube.com/user/rederecord

As restrições foram: voz masculina, discurso jornalístico e notícia completa sem interrupção. Utilizamos o software Adobe Audition para as amostras. A análise acústica do corpus se fez com o software Speech Filing System, que converteu os dados sonoros em uma lógica compreensível para a rotina ExProsódia. As amostras foram filtradas individualmente para a remoção de ruídos e sons alheios à análise.

\section{Resultados}

Na Tabela 1, os resultados das amostras foram separados por falante (marcados nas linhas pelos números), tipo de amostra (feliz/agradável e triste/desagradável) e resultados de análise (frequência média e tom médio). Não encontramos nenhum padrão ao analisar as estruturas como um todo. As amostras foram produzidas sem diferenças quanto à alteração de frequência média e tom médio. $O$ teste de correlação não mostrou um $r^{2}$ significativo para a comparação entre as categorias semânticas (feliz ou triste) e as categorias de tom médio e de frequência média. Pela proximidade dos resultados (6 de 15 pares tristes/desagradáveis menores que os pares alegres/agradáveis, 4 de 15 pares tristes maiores que os alegres e 5 de 15 com resultados iguais) podemos dizer que não há um padrão na comparação de resultados comparados entre si. 


\begin{tabular}{|lll|lll|}
\hline Feliz & $\begin{array}{l}\text { Freq. } \\
\text { média }\end{array}$ & $\begin{array}{l}\text { Tom } \\
\text { médio }\end{array}$ & Triste & $\begin{array}{l}\text { Freq. } \\
\text { média }\end{array}$ & $\begin{array}{l}\text { Tom } \\
\text { médio }\end{array}$ \\
\hline $1-$ & 124,9971 & b1 & $1-$ & 122,141 & b1 \\
2- & 130,7052 & c2 & $2-$ & 131,7589 & c2 \\
$3-$ & 146,4579 & d2 & $3-$ & 144,757 & d2 \\
$4-$ & 160,222 & e2 & $4-$ & 158,3903 & d\#2 \\
$5-$ & 150,8299 & d2 & $5-$ & 159,6148 & d\#2 \\
$6-$ & 178,466 & f2 & $6-$ & 181,871 & f\#2 \\
$7-$ & 183,3938 & f\#2 & $7-$ & 196,6561 & g2 \\
$8-$ & 168,9232 & e2 & $8-$ & 187,5074 & f\#2 \\
9- & 174,9827 & f2 & $9-$ & 163,3822 & e2 \\
$10-$ & 203,9993 & g\#2 & $10-$ & 178,2342 & f2 \\
$11-$ & 122,9202 & b1 & $11-$ & 124,9738 & b1 \\
$12-$ & 155,2668 & d\#2 & $12-$ & 159,0695 & d\#2 \\
$13-$ & 155,6733 & d\#2 & $13-$ & 163,0269 & e2 \\
$14-$ & 126,0693 & b1 & $14-$ & 131,2227 & c2 \\
$15-$ & 114,4568 & a\#1 & $15-$ & 99,42589 & g1 \\
\hline
\end{tabular}

Tabela 1. Resultados obtidos

\section{Considerações finais}

Segundo Wennerstrom (2001), há possibilidade destes padrões estarem combinados com estruturas semânticas das orações. Uma possibilidade é essas estruturas que "marcam" a emoção na fala estarem nos fonemas, como define Grammont (1933). 